\title{
JOURNAL.RU
}

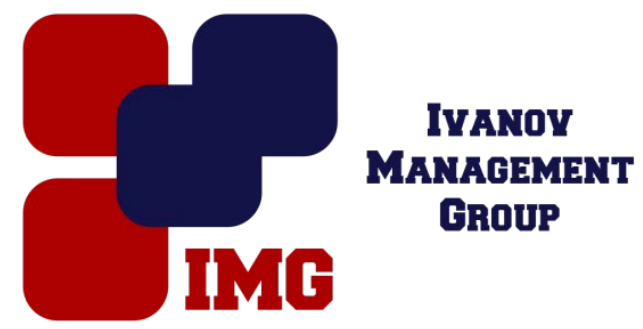

Alhousni A.H., Konovalov I.E. Volga state academy of physical culture, sport and tourism

Kazan, Russia

doi: 10.18411/lj-28-02-2017-1-04

idsp 000001:lj-28-02-2017-1-04

\section{Identify the mosteffective and important Factors which limiting of the development of the performance of sprinters}

\section{Annotation}

It can be happened that the sprinter reach a limited level , does not happen after it evolution for performance. Or happens a slowly evolution not equal the capabilities in the sprinter ,all of this could be happens because of one mistake during the training process, which is not clear for a coach or sprinter .the current high level for sprinters around the world , Do not leave any chance for a breakthrough athlete with a simpler effects .Even if the extreme elements of the talent and the willingness for sprinter were available , In this article, we works to draw attention to some of these factors to correct or not to make them . Is also working to determine which one of these factors is more Frequent, and the greatest impact.

\section{Research tasks:}

1. Identify the factors which limiting develop the performance of sprinters in Kazan city.

2. Identify any of these factors more widespread and effective.

In the result we hope to get to know the most important specific performance factors, and treatment of existing ones, and to draw the attention of coaches to avoid the appearance of the common ones, which will allow the correct development of the sprinters .

It is enough to know, for example, Jamaican sprinter Usain Bolt suffered torso angle a little more conventional front during the run ,Which had a negative impact on his the performance , But help's coach Glen Mills for him contributed to solve this problem, and improve his level in correct way.

Thus, to draw the attention coaches of Kazan city to the most formative errors spread and impact, which will have a great benefit through avoided in the future in terms of the use of pre-existing ways to avoid them, or create new ways to deal with them in a correct way. 


\section{The most popular and affective factorsfor sprinting}

Through our searching in multiple scientific references We could initially consider some of the factors that have long existed among runners around the world

Studying whether the impact is really enough to make sprinter level in the natural course.

\section{1 - The correct running technique}

Fire 2002 identifies following parameters effective style to run

- Recovery higher heel once you foot leaves ground Fulcrum

- feet touch the ground near as possible from the point on the bottom of bodymass.

- Must ankle swing forward to cross the pivot feet above the knee

- Backslash arms when attached back as if they reach to put a pocket in the thigh.

- Relax your hands and shoulders, neck and jaw and face

- Upright head and eyes on the finish line focusing

- running over a straight line with a very small amount of side movements

2 - the Step length

for sprinters , the average step length in distance between 60 to $100 \mathrm{~m}$ Should be equal to the tall of sprinter $+40 \%$ of his tall the average step length in distance between 30 to 60 meters It should equal to the length of sprinter $+20 \%$ of his tall

\section{3 - The correct starting technique}

sprinter must achieve increase of $15 \mathrm{~cm}$ each step from the previousone, in the first seven steps which well be taken in the first $10 \mathrm{~m}$

\section{4 - speed reducingreducing in the last $30 \mathrm{~m}$}

The reduced speed in the $30-\mathrm{m}$ final at about $3 \%$ part of a second will be regular and routine, but this reduced speed of more than $10 \%$ of a second explains that the sprinter has lost part of his capabilities

\section{5 - sprinter ideal weight}

sprinter ideal weight should be $42.5 \%$ of his tall.

\section{Conclusions}

taking into account the above factors the as appropriate for the compensate for the loss in time through correcting running or starting technique sprinter, or modify its weight to approach as much as possible from the ideal weight or work to raise the frequency of running speed , or continue to the end without delay will give the sprinter the chance to develop his performance to high levels , and when we have a clear idea about the most affective and repeating the coaches will be attention to deal with them and the researchers will directingthere to find a new creative solutions. 


\section{Литература}

1. Алхусни, А. Х.Определение наиболее важных факторов, которые ограничивают производительность спринтеров / А.Х. Алхусни, И.Е. Коновалов // Актуальные проблемы теории и практики физической культуры, спорта и туризма: материалыV межвузовской научно-практической конференции молодых ученых, аспирантов, магистрантов и студентов. -Казань: Поволжская ГАФКСиТ, 2016. - С.304-305.

2. Hadzhar.O, the factors that determine the time-streaming athletics release the 2004 bulletinC12 35_40.

3. the best exercises sprinters, athletics bulletin-2 graduates 2000 s14-18.

4. the development of muscle strength for children reservations and reality-Refat Osman -Easy lifting-Newsletter Issue 17 Cairo 2006 s6_12.

5. Postavisi.A, cliometrics to training in athletics, athletics Bulletin-19 graduates in 2006, s32_36. 